\title{
Perbandingan Efektivitas Anestesi Spinal dengan Bupivacain 12,5 Mg dan Bupivacain 5 Mg yang ditambah Fentanyl 50 Mcg pada Seksio Sesarea
}

\author{
Fritzky Indradata, Heri Dwi Purnomo, Muh. Husni Thamrin, Sugeng Budi Santoso, Ardana Tri \\ Arianto, RTH Supraptomo
}

Departemen Anestesiologi \& Terapi Intensif Fakultas Kedokteran Universitas Sebelas Maret-RSUD Dr. Moewardi

Surakarta

\begin{abstract}
Abstrak
Latar Belakang: Anestesi spinal mempunyai efek samping berupa hipotensi dan mual muntah. Tujuan: penelitian ini adalah membandingkan efek anestesi spinal bupivacain dosis normal 12,5 mg dan bupivacain dosis rendah $5 \mathrm{mg}$ dengan fentanyl $50 \mathrm{mg}$ pada seksio sesarea terhadap perubahan hemodinamik, ketinggian blok, onset, durasi dan efek samping.

Subjek dan Metode: Penelitian double blind randomized control trial pada 36 pasien yang memenuhi kriteria. Pasien dibagi menjadi dua kelompok, yang masing-masing terdiri 18 pasien, kelompok 1 dilakukan anestesi spinal dengan bupivacain hiperbarik $5 \mathrm{mg}$ ditambah adjuvan fentanyl $50 \mathrm{mcg}$, sedangkan kelompok 2 diberikan bupivacain hiperbarik 12,5 mg. Penilaian meliputi saat mula kerja blokade sensorik, mula kerja blokade motorik, durasi, tekanan darah, laju nadi, dan saturasi oksigen, lama kerja dan efek samping. Data hasil penelitian diuji secara statistik dengan uji chi-square.

Hasil: Terdapat perbedaan signifikan pada onset dan durasi blokade sensorik dan motorik, bupivacain 12,5 mg lebih baik dibandingkan bupivacain $5 \mathrm{mg}+$ fentanyl $50 \mathrm{mcg}(\mathrm{p}<0.05)$. Tidak ada perbedaan signifikan pada perubahan tanda vital dan efek samping $(\mathrm{p}>0.05)$.

Simpulan: Bupivacain 12,5 mg menghasilkan onset lebih cepat dan durasi lebih lama dibandingkan bupivacain 5 $\mathrm{mg}+$ fentanil $50 \mathrm{mcg}$ pada anestesi spinal untuk seksio sesarea
\end{abstract}

Kata kunci: seksio sesarea, anestesi spinal, bupivacain, fentanyl, efektifitas

\section{Comparison of The Effectiveness Spinal Anesthesia with Bupivacaine 12,5 Mg and Bupivacaine 5 Mg added Fentanyl 50 Mcg in Caesarean Section}

\begin{abstract}
Background: Spinal anesthesia has side effects such as hypotension and nausea and vomiting.

Objective: The aim of this study was to compare the effects of spinal anesthesia with normal doses of 12,5 mg of bupivacaine and $5 \mathrm{mg}$ of low-dose bupivacaine with fentanyl $50 \mathrm{mg}$ in the cesarean section on hemodynamic changes, block height, onset, duration, and side effects.

Subjects and Methods: Double-blind randomized control trial in 36 patients who met the criteria. Patients were divided into two groups, each consisting of 18 patients, group 1 underwent spinal anesthesia with $5 \mathrm{mg}$ of hyperbaric bupivacaine plus 50 mcg of fentanyl adjuvant, while group 2 was given $12,5 \mathrm{mg}$ of hyperbaric bupivacaine. Assessments include the initiation of sensory block action, onset of motor block action, duration, blood pressure, pulse rate, and oxygen saturation, duration of action, and side effects. The research data were statistically tested with the chi-square test.

Results: There were significant differences in the onset and duration of sensory and motor blockade, bupivacaine $12,5 \mathrm{mg}$ was better than bupivacaine $5 \mathrm{mg}+$ fentanyl $50 \mathrm{mcg}(\mathrm{p}<0.05)$. There was no significant difference in changes in vital signs and side effects $(\mathrm{p}>0.05)$.

Conclusion: Bupivacaine 12,5 $\mathrm{mg}$ resulted in a faster onset and longer duration than bupivacaine $5 \mathrm{mg}+$ fentanyl $50 \mathrm{mcg}$ in spinal anesthesia for cesarean section.
\end{abstract}

Keywords: cesarean section, spinal anesthesia, bupivacaine, fentanyl, effectiveness 


\section{Pendahuluan}

Anestesi spinal menjadi pilihan yang paling sering pada seksio sesarea, selain mengurangi polifarmasi pada anestesi umum yang dapat berefek pada janin, dengan anestesi spinal ibu masih sadar dan mungkin mendengar tangisan bayi dengan efek psikologis tersendiri. ${ }^{1}$ Akan tetapi, anestesi spinal juga memiliki kelemahan atau potensi efek samping baik pada ibu maupun pada janin, hingga terjadinya fetal asidosis. ${ }^{2}$ Efek samping anestesi spinal paling sering berupa hipotensi dan kejadian mual muntah yang dapat mengganggu proses operasi. Mekanisme hipotensi dapat dijelaskan sebagai efek blok simpatis yang menyebabkan vasodilatasi arteri dan arteriolar; adanya venodilatasi menyebabkan preload jantung menurun, mengurangi curah jantung dan menyebabkan hipotensi ibu. Pada kehamilan, diperparah oleh efek dari uterus gravid dan kompresi aortocaval. Hipotensi dapat juga menyebabkan mual dan muntah, iskemia organ, kolaps kardiovaskular, dan pada kasus kehamilan dapat membahayakan janin. ${ }^{3}$

Berbagai upaya preventif sudah diteliti dan dilakukan untuk mencegah efek buruk anestesi spinal, terutama hipotensi. Upaya-upaya tersebut antara lain adalah preloading kristaloid sebelum operasi, posisi ibu miring ke kiri, hingga obatobatan seperti efedrin. ${ }^{4}$ Upaya-upaya tersebut tidak seluruhnya menghilangkan efek samping hipotensi, sehingga muncul pemikiran untuk menurunkan dosis anestesi lokal. Beberapa buku teks anestesi merekomendasikan dosis bupivakain untuk seksio sesarea antara 12 hingga 15 mg. ${ }^{5}$ Namun, rentang dosis ini telah dikaitkan dengan kejadian hipotensi ibu sebesar 69\% hingga 80\% yang mengakibatkan morbiditas ibu dan bayi baru lahir. ${ }^{6}$ Sejumlah penelitian untuk mencari dosis optimal bupivakain menghasilkan temuan yang berbeda yaitu dengan dosis mulai dari 5 hingga $20 \mathrm{mg}^{7}$ Dosis lebih rendah bertujuan mengurangi efek samping ibu (hipotensi dan mual muntah). ${ }^{7}$ Satu penelitian menyimpulkan bahwa anestesi spinal dosis rendah efektif mengurangi ketidakstabilan hemodinamik ibu. ${ }^{8}$ Penelitian lain juga menyimpulkan bahwa insiden hipotensi ibu dan kebutuhan vasopressor berkurang pada wanita yang menjalani persalinan operatif. ${ }^{9}$ Berdasarkan latar belakang tersebut, akan dibandingkan efek bupivakain dosis normal yaitu 12,5 mg dengan bupivakain dosis rendah yaitu $5 \mathrm{mg}$ yang ditambahkan fentanyl $50 \mathrm{mg}$.

\section{Subjek dan Metode}

Penelitian ini merupakan double blind randomized control trial untuk membandingkan pengaruh bupivacain $5 \mathrm{mg}$ yang ditambah fentanyl $50 \mathrm{mcg}$ dan bupivakain $12,5 \mathrm{mg}$ sebagai anestesi spinal. Total sampel penelitian 36 pasien, 18 pasien mendapat bupivacain hiperbarik $5 \mathrm{mg}$ ditambah adjuvan fentanyl $50 \mathrm{mcg}$ dan 18 pasien menggunakan bupivacain hiperbarik $12,5 \mathrm{mg}$. Penelitian dilakukan di RSUD Dr. Moewardi Surakarta dan rumah sakit jejaring pada Agustus November 2018. Kriteria inklusi dalam penelitian ini meliputi semua pasien yang dijadwalkan operasi seksio sesarea, status fisik ASA I dan ASA II, lama operasi kurang dari atau sama dengan 2 jam. Kriteria eksklusi dalam penelitian meliputi denyut jantung sebelum operasi $<45 \mathrm{x} /$ menit, pasien hamil dengan kelainan jantung, alergi terhadap obat-obat anestesi, riwayat gangguan penyalahgunaan obat-obatan narkotika psikotropika zat adiktif (NAPZA) atau gangguan psikiatrik, menolak menandatangani informed consent. Adapun kriteria dropout adalah pada pasien yang mengalami Kegagalan anestesi spinal (obat anestesi spinal tidak masuk ke dalam ruang sub-araknoid), high spinal (blokade anestesi lokal di atas T4) atau total spinal (blokade anestesi mencapai setinggi vertebra cervicalis atau di atasnya), pasien merasa nyeri durante operasi.

Secara acak pasien dibagi menjadi dua kelompok, 18 pasien mendapat bupivacain hiperbarik $5 \mathrm{mg}$ ditambah adjuvan fentanyl $50 \mathrm{mcg}$ dan 18 pasien menggunakan bupivacain hiperbarik $12,5 \mathrm{mg}$. Kemudian dilakukan pencatatan saat mula kerja blokade sensorik mencapai level T4 yang dinilai setiap menit, diukur dengan pinprick test. Setelah mencapai T4 operasi dimulai. Lama durasi blokade sensorik diukur dengan waktu regresi sampai T12 yang dinilai setiap 15 menit setelah 60 menit penyuntikan anestesi spinal, diukur dengan pinprick test dan saat pertama kali pasien merasa 
nyeri ringan sampai dengan NRS $>3$ yang dinilai setiap 30 menit setelah 60 menit penyuntikan obat anestesi spinal, kemudian pasien diberi analgetik intravena fentanyl $0,5 \mathrm{mcg} / \mathrm{kgBB} / \mathrm{jam}$ dikombinasi dengan parasetamol $1 \mathrm{~g} / 8 \mathrm{jam}$.

Tekanan darah, laju nadi, dan saturasi oksigen diukur tiap 5 menit setelah suntikan selama 30 menit pertama, tiap 10 menit pada 30 menit kedua, tiap 15 menit pada 30 menit ketiga sampai operasi selesai, dan selanjutnya tiap 30 menit sampai efek blokade menghilang (Bromage skor 0). Selama operasi dan pasca operasi kejadian hipotensi, bradikardia dicatat. Selama operasi berlangsung dilakukan pencatatan banyaknya penggunaan cairan, efedrin, dan sulfas atropin. Data dianalisis dengan program SPSS 17.0. Variabel demografi dicari nilai reratanya dan perbandingan variabel masing-masing kelompok diuji menggunakan uji Chi-square dan uji Mann Whitney U untuk data nominal dan ordinal, sedangkan untuk data kontinyu diuji dengan independent-t test.

\section{Hasil}

Penelitian dilakukan di RSUD Dr. Moewardi Surakarta dan RS Jejaring pada bulan Agustus November 2018. Sebanyak 36 pasien yaitu pasien hamil dengan tindakan seksio sesarea dan anestesi spinal, status fisik ASA I dan II, bersedia ikutserta dalam penelitian, Total sampel 36 pasien, terdiri dari 18 pasien diberi bupivacain hiperbarik $5 \mathrm{mg}$ ditambah adjuvan fentanyl $50 \mathrm{mcg}$, dan 18 pasien diberi bupivacain hiperbarik 12,5 mg. Pencatatan dilakukan untuk menilai perbedaan kecepatan onset dan pemanjangan durasi blokade sensorik dan motorik, gejolak hemodinamik dan efek samping obat.

Karakteristik Dasar Subjek Penelitian

Tabel 1. Karakteristik Dasar Subjek Penelitian

\begin{tabular}{|c|c|c|c|c|}
\hline Variabel & B5F50 & $\mathrm{C}$ & Total & P-value \\
\hline Pendidikan $^{1}$ & & & & 0,097 \\
\hline $\mathrm{SD}$ & $0(0,0 \%)$ & $0(0,0 \%)$ & $0(0,0 \%)$ & \\
\hline SMP & $1(5,6 \%)$ & $1(5,6 \%)$ & $2(5,6 \%)$ & \\
\hline SMA & $17(94,4 \%)$ & $13(72,2 \%)$ & $30(83,3 \%)$ & \\
\hline PT & $0(0,0 \%)$ & $4(22,2 \%)$ & $4(11,1 \%)$ & \\
\hline $\mathrm{Usia}^{3}$ (tahun) & $28,56 \pm 6,45$ & $31,44 \pm 7,82$ & $30,00 \pm 7,22$ & 0,295 \\
\hline Tinggi Badan² $(\mathrm{cm})$ & $153,72 \pm 4,53$ & $155,17 \pm 3,93$ & $154,44 \pm 4,25$ & 0,314 \\
\hline 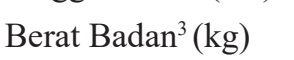 & $71,72 \pm 11,75$ & $73,11 \pm 12,28$ & $72,42 \pm 11,87$ & 0,937 \\
\hline
\end{tabular}

Keterangan: ${ }^{1}$ Data Kategori Ordinal (Jumlah, Prosentase) Uji Mann Whitney, ${ }^{2}$ Data numerik distribusi normal $($ Mean + SD ) Uji independent tes; karakteristik pasien dalam penelitian ini homogen (nilai $\mathrm{p}>0,05)$ (Tabel 1) B5F50: Bupivacain $5 \mathrm{mg}+$ fentanyl 50mcg; BP 12, 5: Bupivacain 12,5 mg.

Tabel 2. Lama Kerja Blokade Sensorik

\begin{tabular}{lccc}
\hline \multicolumn{1}{c}{ Variabel } & Bupivacain 5 mg + fentanyl 50 mcg & Bupivacain 12,5 mg & P-value \\
\hline T6 (NRS $<3)^{2}$ & $3,56 \pm 1,50$ & $2,22 \pm 1,06$ & 0,002 \\
Blokade Tertinggi $^{1}$ & $4,00 \pm 0,34$ & $4,00 \pm 0,00$ & 1,000 \\
T8 $^{2}$ & $58,33 \pm 7,48$ & $88,89 \pm 7,58$ & 0,000 \\
NRS $>3{ }^{2}$ & $91,11 \pm 4,71$ & $122,78 \pm 8,26$ & 0,000 \\
\hline
\end{tabular}

Keterangan: Satuan nilai terukur dalam menit kecuali blokade tertinggi; ${ }^{1}$ Data numerik distribusi normal (Mean \pm SD) Uji independent test; ${ }^{2}$ Data numerik distribusi tidak normal (Mean \pm SD ) Uji Mann Whitney

Bupivacain 12,5 mg memiliki kerja lebih cepat dan durasi blokade motorik lebih lama dibandingkan bupivacain $5 \mathrm{mg}$ dengan fentanyl $50 \mathrm{mcg}$ (Tabel 2). 
Tabel 3. Kerja Blokade Motorik

\begin{tabular}{cccc}
\hline Variabel & Bupivacain 5 mg fentanyl 50 mcg & Bupivacain 12,5 mg & P-value \\
\hline Bromage 0-1 & $4,50 \pm 0,99$ & $2,11 \pm 0,96$ & 0,000 \\
Bromage 0-3 & $7,78 \pm 1,83$ & $4,17 \pm 1,89$ & 0,000 \\
Bromage 0-2' & $67,78 \pm 13,09$ & $97,78 \pm 9,43$ & 0,000 \\
Bromage 0-0' & $112,78 \pm 9,58$ & $148,89 \pm 5,83$ & 0,000 \\
\hline
\end{tabular}

Keterangan: Satuan nilai terukur dalam menit; Data numerik distribusi tidak normal (Mean \pm SD ) Uji Mann Whitney

Onset dan Durasi Blokade Sensorik dan Motorik Bupivacain 12,5 mg memiliki kerja lebih cepat dan durasi blokade motorik lebih lama dibandingkan bupivacain $5 \mathrm{mg}$ dengan fentanyl $50 \mathrm{mcg}$ (Tabel 2). Bupivacain $12,5 \mathrm{mg}$ menghasilkan onset lebih cepat dan perpanjangan blokade motorik lebih lama dibandingkan kelompok bupivacain $5 \mathrm{mg}+$ fentanyl $50 \mathrm{mcg}$ (Tabel 3 ).

\section{Tanda Vital Antar Kelompok}

Tidak terdapat perbedaan signifikan tanda vital antara kelompok bupivacain $5 \mathrm{mg}$ yang ditambah fentanyl $50 \mathrm{mcg}$ dengan kelompok bupivacain $12,5 \mathrm{mg}$. Pemberian bupivacain $5 \mathrm{mg}$ yang ditambah fentanyl $50 \mathrm{mcg}$ memiliki dampak pada perubahan tanda vital pasien yang sama dengan kombinasi pemberian bupivacain $12,5 \mathrm{mg}$.

Tabel 4. Tanda Vital Antar Kelompok

\begin{tabular}{|c|c|c|c|}
\hline Variabel & $\begin{array}{l}\text { Bupivacain } 5 \mathrm{mg}+ \\
\text { fentanyl } 50 \mathrm{mcg}\end{array}$ & Bupivacain 12,5 mg & P-value \\
\hline \multicolumn{4}{|c|}{ Sistolik (mmHg) } \\
\hline $\operatorname{Pre}^{1}$ & $126,89 \pm 9,76$ & $130,00 \pm 14,74$ & 0,460 \\
\hline Post $^{1}$ & $118,44 \pm 14,47$ & $118,78 \pm 21,15$ & 0,956 \\
\hline \multicolumn{4}{|c|}{ Diastolik (mmHg) } \\
\hline $\operatorname{Pre}^{2}$ & $75,28 \pm 7,51$ & $78,72 \pm 7,17$ & 0,287 \\
\hline Post $^{1}$ & $71,00 \pm 8,53$ & $64,22 \pm 15,28$ & 0,110 \\
\hline \multicolumn{4}{|c|}{ MAP (mmHg) } \\
\hline $\operatorname{Pre}^{2}$ & $94,28 \pm 7,73$ & $99,06 \pm 12,42$ & 0,234 \\
\hline Post $^{1}$ & $87,17 \pm 10,36$ & $86,06 \pm 16,22$ & 0,808 \\
\hline \multicolumn{4}{|c|}{ Laju Nadi (kali/menit) } \\
\hline $\operatorname{Pre}^{1}$ & $88,61 \pm 11,88$ & $95.56 \pm 10,35$ & 0,070 \\
\hline Post $^{2}$ & $86,44 \pm 13,79$ & $88,94 \pm 12.71$ & 0,657 \\
\hline \multicolumn{4}{|l|}{$\mathrm{SpO}_{2}(\%)$} \\
\hline $\mathrm{Pre}^{2}$ & $99,83 \pm 0,38$ & $99,67 \pm 0,49$ & 0,255 \\
\hline Post $^{2}$ & $99,83 \pm 0,38$ & $99,67 \pm 0,49$ & 0,255 \\
\hline
\end{tabular}

Keterangan: ${ }^{1}$ Data numerik distribusi normal (Mean \pm SD ) Uji independent test; ${ }^{2}$ Data numerik distribusi tidak normal (Mean \pm SD ) Uji Mann whitney

\section{Efek Samping Antar Kelompok}

Efek samping dua perlakuan tidak terdapat perbedaan yang signifikan, penggunaan kedua obat tidak berdampak pada meningkatnya efek samping (Tabel 5). Efek samping paling sering ditemukan pada kelompok bupivacain 12,5 mg yaitu hipotensi $(11,1 \%)$ dan mual/muntah $(5,6 \%)$, sedangkan pada kelompok Bupivacain $5 \mathrm{mg}$ dengan fentanyl $50 \mathrm{mcg}$ tidak ditemukan adanya efek samping. 
Tabel 5. Efek Samping

\begin{tabular}{llll}
\hline Variabel & $\begin{array}{l}\text { Bupivacain 5 mg } \\
\text { fentanyl 50 mcg }\end{array}$ & Bupivacain 12,5 mg & P-value \\
\hline Hipotensi & $0(0,0 \%)$ & $2(11,1 \%)$ & 0,486 \\
Bradikardia & $0(0,0 \%)$ & $0(0,0 \%)$ & $\mathrm{N} / \mathrm{S}$ \\
$\begin{array}{l}\text { Penurunan saturasi } \\
\text { oksigen }\end{array}$ & $0(0,0 \%)$ & $0(0,0 \%)$ & $\mathrm{N} / \mathrm{S}$ \\
Nyeri kepala/punggung & $0(0,0 \%)$ & $0(0,0 \%)$ & $\mathrm{N} / \mathrm{S}$ \\
Mual dan atau muntah & $0(0,0 \%)$ & $1(5.6 \%)$ & 1,000 \\
Delirium & $0(0,0 \%)$ & $0(0,0 \%)$ & $\mathrm{N} / \mathrm{S}$ \\
Shivering & $0(0,0 \%)$ & $0(0,0 \%)$ & $\mathrm{N} / \mathrm{S}$ \\
\hline
\end{tabular}

Keterangan: Data Kategori (Jumlah, Prosentase) Uji Chi Square/fisher exact test

$\mathrm{N} / \mathrm{S}=$ Not Specified (karena tidak terdapat variansi atau dapat dikatakan tidak terdapat perbedaan); Tidak terdapat perbedaan signifikan tanda vital antara kelompok bupivacain $5 \mathrm{mg}+$ fentanyl $50 \mathrm{mcg}$ dengan kelompok bupivacain $12,5 \mathrm{mg}$. Pemberian bupivacain $5 \mathrm{mg}$ + fentanyl $50 \mathrm{mcg}$ memiliki dampak pada perubahan tanda vital pasien yang sama dengan kombinasi pemberian bupivacain $12,5 \mathrm{mg}$.

\section{Pembahasan}

Anestesi spinal adalah anestesi yang diinduksi oleh sejumlah kecil anestesi lokal ke dalam cairan serebrospinal. Injeksi dilakukan pada vertebrae lumbal setinggi L3-L4. Pasien memiliki tinggi badan $155 \mathrm{~cm}$ sehingga memungkinkan untuk dilakukan anestesi spinal. Anestesi spinal mudah dilakukan dan berpotensi memberikan kondisi seksio sesarea yang baik pada area di bawah umbilicus. ${ }^{10}$

Anestesi spinal menjadi pilihan yang paling sering pada operasi sesar karena selain mengurangi polifarmasi seperti pada anestesi umum yang dapat berefek pada janin, pada anestesi spinal ibu masih dalam keadaan sadar dan mungkin mendengar tangisan bayi yang memiliki efek psikologis tersendiri. ${ }^{1}$ Penambahan fentanyl intratekal sebesar $50 \mathrm{mcg}$ sampai 100 mcg meningkatkan secara signifikan durasi dan kualitas analgesi, tetapi berhubungan dengan risiko depresi nafas. ${ }^{11}$ Teknik spinal dosis rendah pada ibu hamil menggunakan 5 mg bupivakain dengan penambahan fentanyl 50 mcg terbukti mampu memberikan analgesia yang adekuat dengan hemodinamik stabil dibandingkan efek bupivakain dosis normal yaitu $12,5 \mathrm{mg} .{ }^{12}$

Hasil penelitian ini menunjukkan bahwa kombinasi bupivacain $5 \mathrm{mg}$ dengan fentanyl
$50 \mathrm{mcg}$ memiliki efek blokade sensorik yang berbeda signifikan dari bupivacain $12,5 \mathrm{mg}$; onset lebih lama dan durasi lebih singkat. Tetapi bupivacain 12,5 mg memberikan efek blokade sensorik yang terbaik. Perbandingan blokade sensorik bupivacain $5 \mathrm{mg}+$ fentanyl $50 \mathrm{mcg}$ dengan bupivacain $12,5 \mathrm{mg}$ pada T6 $(3,56 \pm 1,50$ vs $2,22 \pm 1,06) \mathrm{p}=0,002, \mathrm{~T} 8$ $(58,33 \pm 7,48$ vs $88,89 \pm 7,58) \mathrm{p}=0,000$, dan NRSS $>3(91,11 \pm 4,71 \mathrm{vs} 122,78 \pm 8,26) \mathrm{p}=0,000$. Pada blokade motorik, efek kombinasi bupivacain $5 \mathrm{mg}+$ fentanyl $50 \mathrm{mcg}$ dibandingkan dengan kelompok bupivacain $12,5 \mathrm{mg}$ onsetnya lebih lama dan durasi lebih pendek. bupivacain 12,5 mg memberikan efek blokade motorik yang terbaik. Perbandingan blokade montorik bupivacain $5 \mathrm{mg}$ dan fentanyl $50 \mathrm{mcg}$ dengan bupivacain $12,5 \mathrm{mg}$ pada bromage $0-1(4,50 \pm 0$ ,99 vs $2,11 \pm 0,96) \mathrm{p}=0,000$, bromage $0-3(7,78$ $\pm 1,83$ vs $4,17 \pm 1,89) \mathrm{p}=0,000$, bromage $0-2$ ' $(6,78 \pm 13,09$ vs $97,78 \pm 9,43)$, dan bromage $0-0{ }^{\prime}(112,78 \pm 9,58$ vs $148,89 \pm 5,83) \mathrm{p}=0,000$.

Penelitian ini juga menunjukkan bahwa bupivacain $5 \mathrm{mg}$ dengan fentanyl $50 \mathrm{mcg}$ mempunyai waktu pulih lebih cepat. Diketahui bahwa onset dan durasi anestesi lokal dipengaruhi oleh konsentrasi obat, dosis, lipid solubility, PKa, $\mathrm{pH}$ dan protein binding. ${ }^{2}$ Onset yang lama dan durasi yang singkat pada penelitian ini dapat disebabkan karena penambahan fentanyl $50 \mathrm{mcg}$ 
dan volume barbotase mempengaruhi konsentrasi bupivacain menjadi lebih rendah, sehingga mempengaruhi protein binding bupivacain. Sebuah penelitian mendapatkan hasil 7,6 mg dan 11,2 $\mathrm{mg}$ sebagai dosis efektif bupivakain.

Dosis ideal obat anestesi lokal untuk seksio sesarea adalah keseimbangan antara kenyamanan pasien dan menghindari efek samping maternal, yaitu hipotensi dan mual. Banyak peneliti berpendapat bahwa meningkatkan dosis obat analgesi lokal akan meningkatkan hipotensi maternal dan mual dengan hasil akhir penurunan kepuasan pasien. ${ }^{13}$ Bupivakain $5 \mathrm{mg}$ isobarik mengurangi insiden hipotensi, mual dan penggunaan vasopresor. ${ }^{7}$ Kadar puncak plasma bupivacain tercapai setelah 30-45 menit, turun dalam 3-6 jam. Waktu paruh bupivacain pada orang dewasa adalah 2,7 jam sedangkan pada neonatus 8,1 jam. $^{7}$ Fentanyl memiliki onset cepat, tetapi durasinya singkat yakni sekitar 15-30 menit. Obat ini dapat diberikan secara intravena, epidural, atau intratekal. Fentanyl epidural digunakan untuk induksi anestesi dan analgesia pasca operasi. Sediaan transmukosal digunakan untuk untuk perawatan pasien kanker yang toleran terhadap opioid. Patch transdermal dapat digunakan sebagai analgetik pascabedah pada operasi ortopedi ekstremitas bawah dikombinasi dengan ketorolak $30 \mathrm{mg}$ intravena. ${ }^{14}$ Hasil penelitian ini juga menunjukkan bahwa kombinasi bupivacain $5 \mathrm{mg}$ dengan fentanyl 50 mcg memiliki dampak pada perubahan tekanan darah sistolik dan diastolik, tekanan arteri ratarata, laju nadi, dan $\mathrm{SpO}_{2}$ yang tidak berbeda signifikan dari bupivacain $12,5 \mathrm{mg}$.

Efek samping dua perlakuan tersebut tidak berbeda signifikan dan tidak terlalu banyak. Anestesi spinal berisiko komplikasi; terbagi atas komplikasi mayor, moderat dan minor. Sebagian besar komplikasi mayor jarang terjadi; sedangkan komplikasi minor sering terjadi dan tidak boleh diabaikan. Komplikasi minor meliputi mual, muntah, hipotensi ringan, menggigil, gatal, gangguan pendengaran, dan retensiurin. Postdural puncture headache (PDPH) dan kegagalan blokade spinal merupakan komplikasi anestesi spinal yang signifikan dan tidak jarang terjadi. Penggunaan anestesi spinal dosis rendah untuk menurunkan efek samping seperti hipotensi, mual, dan muntah sudah mulai sering dilakukan. Satu penelitian mengatakan bahwa bupivakain dosis rendah pada anestesi spinal memiliki efektivitas anestesi yang rendah, meskipun dapat menurunkan efek samping hipotensi, mual, dan muntah pada ibu. ${ }^{15}$ Penelitian lain meneliti kemungkinan penurunan angka hipotensi, mual, dan muntah pada ibu jika dosis bupivacain diturunkan. Hasilnya didapatkan bahwa penurunan dosis bupivacaine menjadi $7,5 \mathrm{mg}$ dari yang biasanya $10 \mathrm{mg}$ terbukti menurunkan angka kejadian hipotensi, mual dan muntah. ${ }^{15}$ Dosis spinal bupivacain 4,5 mg sampai $15 \mathrm{mg}$ telah digunakan dengan hasil baik untuk seksio sesarea. Pada ibu hamil, dosis anestesi lokal lebih kecil dibandingkan pada orang normal karena beberapa alasan: (1) volume cairan cerebrospinal lebih sedikit, (2) anestesi lokal hiperbarik akan bergerak ke sefalad saat ibu hamil posisi supine, dan (3) sensitivitas serabut saraf terhadap anestesi lebih besar lokal. Selain itu faktor penggunaan adjuvan opioid juga berpengaruh pada penggunanan dosis yang lebih rendah. ${ }^{16}$

\section{Simpulan}

Pada penelitian anestesi spinal pada seksio sesarea ini tidak terdapat perbedaan signifikan pada perubahan hemodinamik, ketinggian blok, efek samping antara dosis bupivacain $12,5 \mathrm{mg}$ dan bupivacain $5 \mathrm{mg}$ yang ditambah fentanil 50 mcg. Bupivacain 12,5 mg menghasilkan onset lebih cepat dan durasi lebih lama dibandingkan bupivacain $5 \mathrm{mg}$ yang ditambah fentanil $50 \mathrm{mcg}$ pada anestesi spinal untuk seksio sesarea

\section{Daftar Pustaka}

1. Bajwa SJ, Bajwa SK. Anaesthetic challenges and management during pregnancy:2013; 7(2): 160-67.

2. Hadzic A. Textbook of Regional Anesthesia and Acute Pain Management. McGraw-Hill. 2007

3. Velde VM. Spinal anesthesia in the obstetric patient: prevention and treatment of 
hypotension. Acta Anæsthesiologica Belgica. 2006; 57(4):383-6.

4. Hughes SC, Gershon L, Rosen M. 2002. Shnider and Levinson's Anesthesia for Obstetrics 4th ed. Philadelphia: Lippincot William \& Wilkins. 2003, (98): 800-01

5. Tsen L. Anesthesia for cesarean delivery. Obstetric Anesthesia: Principles and Practice. Philadelphia: Elsevier Mosby, 2009; (26): 521-73

6. Lee A, Ngan Kee WD, Gin T. Prophylactic ephedrine prevents hypotension during spinal anesthesia for cesarean delivery but does not improve neonatal outcome: a quantitative systematic review. Can J Anaesth 2002; 49: 588-99.

7. Ben-David B, Miller G, Gavriel R, Gurevitch A. Low-dose bupivakain-fentanil spinal anesthesia for cesarean delivery. Regional Anesthesia and Pain Medicine. 2000;25(3):235-9.

8. McNaught AF, Stocks GM. Epidural volume extension and low-dose sequential combined spinal-epidural blockade: two ways to reduce spinal dose requirement for caesarean section. Int J Obstet Anesth 2007;16:346-353.

9. Ghazi A, Raja Y. Combined low-dose spinalepidural anaesthesia versus single-shot spinal anaesthesia for elective caesarean delivery. Int J Obstet Anesth 2007; 16:90-91.

10. Butterworth JF, Mackey DC, Wasnick JD. Morgan and Mikhail's Clinical
Anesthesiology 5 th ed. McGraw-Hill. 2013.

11. Moshiri E Mozami F, Khoshraftar E. Comparison of the duration of sensory block and side effects of adding different dose of intrathecal fentanyl to lidocain 5\% in spinal Anesthesia. Aviciena J Clin Med. 2012, 19 (1): 5-10.

12. Isngadi. Manajemen Anestesi Pada Kehamilan Dengan Penyakit Jantung. Departemen Anestesiologi dan Terapi Intensif Fakultas Kedokteran Universitas Brawijaya RSUD Dr Saiful Anwar. 2017.

13. Ginosar Y, Mirikatani E, Drover DR, Cohen SE, Riley ET. ED50 and ED95 of intrathecal hyperbaric bupivakain coadminister with opioid in cesarean delivery. Anesthesiology 2004;100:676-82.

14. Rini PN, Ihsan M, Lubis A. Perbandingan efektivitas kombinasi fentanyl patch 12,5 $\mu \mathrm{g} / \mathrm{jam}$ dan $25 \mu \mathrm{g} / \mathrm{jam}$ dengan ketorolak $30 \mathrm{mg}$ intravena pada pascabedah ortopedi ekstremitas bawah. JAP. 2016.4 (2): 95-102.

15. Arzola C, Wieczorek PM. Efficacy of lowdose bupivakain in spinal anaesthesia for Caesarean delivery: systematic review and meta-analysis. $\mathrm{Br} \mathrm{J}$ Anesth. 2011; 107(3):308-18.

16. Chestnut D, Wong C, Tsen L, Ngan Kee DW, Beilin Y, Mhyre J. Chestnut's Obstetric Anesthesia: Principle and Practice, 5th edition. Elsevier Saunders. 2014. 